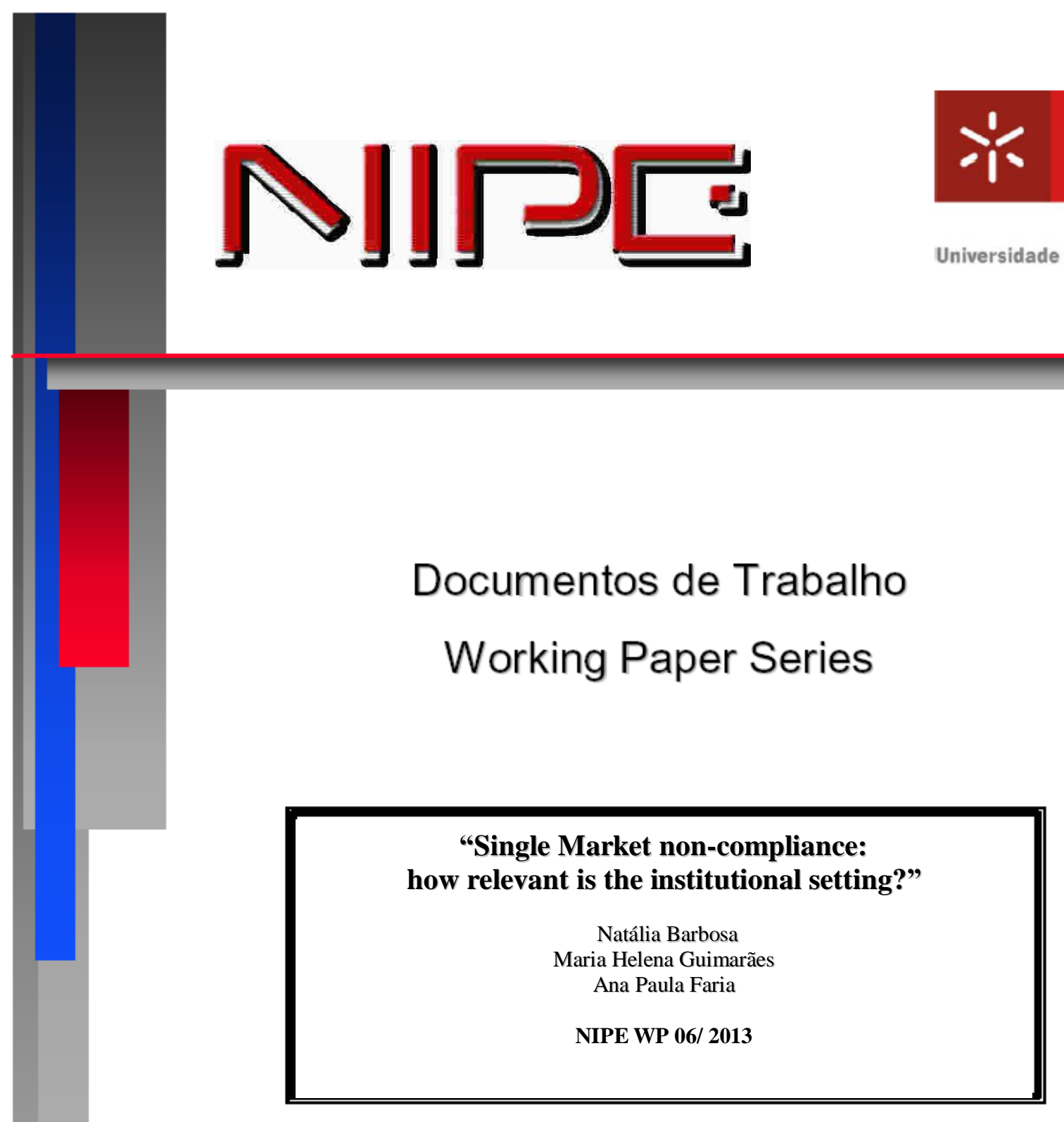

NÚCLEO DE INVESTIGAÇÃO EM POLÍTICAS ECONÓMICAS UNIVERSIDADE DO MINHO 


\section{"Single Market non-compliance: how relevant is the institutional setting?"}

Natália Barbosa

Maria Helena Guimarães

Ana Paula Faria

NIPE* WP 06/ 2013

URL:

http://www.eeg.uminho.pt/economia/nipe
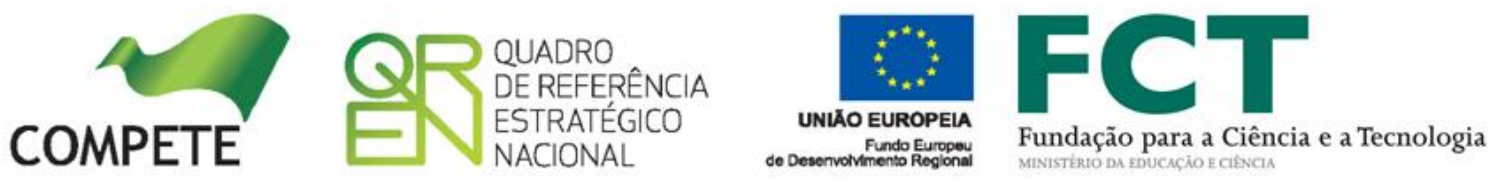


\title{
Single Market non-compliance: how relevant is the institutional setting?
}

\author{
Natália Barbosa, Maria Helena Guimarães* and Ana Paula Faria
}

Natália Barbosa is Associate Professor at Universidade do Minho - Department of Economics (Portugal). natbar@eeg.uminho.pt.

Maria Helena Guimarães is Associate Professor at Universidade do Minho, Department of Economics (Portugal). guimarmh@eeg.uminho.pt.

Ana Paula Faria is Assistant Professor at Universidade do Minho Department of Economics (Portugal). apfaria@eeg.uminho.pt

\begin{abstract}
This paper investigates the role of the national institutional setting of EU member states in explaining Single Market non-compliance regarding non-tariff barriers in intra-EU trade. This study uses data on infringements to Single Market law on the free movement of goods. After controlling for country and industry-specific factors, we show that domestic institutional characteristics are relevant to explain noncompliance ensuing from trade protection measures implemented by EU countries. While government independence from political pressures and higher levels of representativeness and accountability reduce the propensity of member states to infringe upon Single Market laws on the free movement of goods, better regulatory quality increases the probability of non-compliance at industry level, suggesting that increases in competition generate protectionist measures that violate Single Market law.
\end{abstract}

Keywords: Single Market, institutional setting, non-compliance, trade protection, non-tariff barriers, count data models.

* Corresponding author 


\section{Introduction}

Although the European Union (EU) is a common market, intra-EU protectionism persists, as governments continue to adopt national protectionist measures that do not comply with Single Market legislation. Using data on infringements in the Single Market that result from member states' use of Non-Tariff Barriers (NTBs) in EU cross-border trade, this study analyzes the role of institutions in explaining Single Market non-compliance.

Two decades after the implementation of the Single Market Program, EU member countries still do not comply with Community law on the free movement of goods by using protectionist measures, particularly NTBs. Various studies point out to the existence of NTBs affecting the free movement of goods in intra-EU trade. Pelkmans (2011), Aussilloux et al. (2011) and Kox et al. (2007) ascertain that the Single Market is still hampered by barriers to market access that impact on the level of market integration. Chen (2004) and Chen and Novy (2011) showed that NTBs persist in certain EU industries and that they increase border effects, with a negative impact on intra-EU trade.

This paper looks at non-compliance with the two basic EC Treaty articles on the free movement of goods in EU cross border trade (articles 28 and 30, presently articles 36 and 38 of the Treaty on the Functioning of the EU). Article 28 stipulates that quantitative restrictions on imports and all measures having equivalent effect shall be prohibited between Member States, while article 30 establishes the 
exceptions to the rule of free movement of goods ${ }^{1}$ clarifying that they should not constitute a means of arbitrary discrimination or a disguised restriction on trade among member states. Member states' NTBs constitute non-compliance with these articles, therefore complaints to the EU Commission about NTBs that result in an infringement proceeding serve as a proxy for the use these protectionist policies among member states.

Our study contributes to fill several gaps in compliance research identified by Angelova, Danwolf and König (2012) recent research synthesis on compliance findings. First, it addresses compliance in the Single Market, a dimension understudied in compliance literature that only recently has been subject of analysis (Egan and Guimarães 2013, Guimarães 2010). Indeed, compliance research has mainly focused on social (e.g. Hartlapp and Leiber 2010; Linos 2007)) and environmental policies (e.g. Börzel 2000; Koutalakis 2004). In addtion, it is a quantitative study on a specific EU policy field. Second, it researches 14 EU member states compliance records, including both Northern and Southern states. Moreover, our analysis includes evidence not only on cross-national differences but also on cross-industry variation in Single Market non-compliance. Finally, this paper explores whether member states' institutions explain variation in Single Market noncompliance ensuing from the implementation NTBs. While the literature on compliance in the EU has pointed out that differences in existing institutions of

\footnotetext{
1 These exceptions are justified, for example, on grounds of public morality or public security, the protection of health and life of humans, animals or plants, the protection of national treasures with historic or archaeological value, or the protection of industrial and commercial property.
} 
member states have implications in compliance levels, no such evaluation has been carried out for Single Market compliance levels.

Our results for Single Market non-compliance indicate that domestic institutional characteristics are relevant to explain non-compliance related to cross-border EU trade protection practices. While government independence from political pressures and higher levels of representativeness and accountability reduce the propensity of member states to infringe upon Single Market law on the free movement of goods, better regulatory quality increases the probability of non-compliance with Single Market rules.

The remainder of the paper is organized as follows. In Section 2 we review the literature. Section 3 presents the empirical model and describes the data. Section 4 presents the econometric approach and the empirical results. Section 5 concludes.

\section{Institutions, compliance and trade protection}

This paper builds on several strands of literature on the role of institutions in explaining compliance in the EU and trade protection. Domestic institutional impacts in member states policies and Europeanization have been widely researched (e.g. Duina and Blithe 1999; Héritier et al. 2001; Börzel and Risse 2003). The literature on EU compliance particularly, has also identified the conditions under which institutions affect compliance records of EU member states (e.g. Giuliani 2003, Hille and Knill 2006, Börzel et al. 2010), but it has not explored how institutional setting impacts on member states' compliance records pertaining to EU cross-border trade legislation. 
The political science literature on institutional effects on trade policy is vast and dates back to Rogowski's (1987) seminal contribution. Busch and Mansfield (2011) and Milner (1999) present two political science literature reviews on the political economy of trade. This literature concludes that the institutional setting is relevant to understand cross-national differences in protection, but it has not explored its role in explaining the propensity to engage in protectionist behavior among a set of countries that belong to the EU Single Market that ostensibly prohibits protectionist policies.

The traditional economics literature on trade protection shows that NTBs are used to supplement tariffs and are determined by political factors and industry characteristics (e.g. Ray 1981; Trefler 1993; Lee and Swagel 1997). The protection for sale model by Grossman and Helpman (1994) initiated the generation of political economy models that have been widely used to explain why countries try to influence trade flows. While some recent studies have attempted to apply and tailor the model for the EU (Belloc and Guerrieri 2008), their purpose was to explain EU trade policy and not intra-EU trade protection. Interest groups influence on policymakers became a prominent explanatory factor of trade protection, and various studies (e.g. Goldberg and Maggi 1999; Gawande and Bandyopadhyay 2000; Imai et al. 2009) have tested its empirical validity.

On the other hand, the economics literature also points out that the institutional setting may affect markets and firms dynamics and consequently they may impact on trade policy demands from interest groups. In particular, domestic firms and industries in distress due to intra-EU competition or due to the domestic regulatory 
framework may demand protection measures such as NTBs that infringe upon EU legislation on cross-border free trade. In fact, the regulatory framework in which firms operate (entry regulations, anti-trust or labor market policies, ease of doing business) is one of the relevant characteristics of the institutional setting that determines firms and markets outcomes (Djankov et al. 2002). Characteristics of member states' institutional settings may explain how responsive governments are to domestic industries' demands for protection. Access to politicians, their responsiveness to interest groups and the use of political influence to advance specific interests like trade protection are also correlated with the institutional setting (Kono 2006, Kono 2009, Ehrlich 2007). Another institutional feature that conditions firms and markets dynamics is the strength of a country's legal system and its ability to enforce contracts and protect property rights (Laeven and Woodruff 2007).

Our research builds on these various strands of literature on the effects of institutions on trade protection and on compliance with EU law. Our main contention is that the institutional setting may drive trade protection among EU member states and particularly may explain member states' variation in noncompliance with Community legislation on the free movement of goods that results from the application of NTBs.

By exploring various dimensions of the domestic institutional setting this study provides a comprehensive account of the role of national institutional features in explaining protectionist behavior among countries that belong to the EU Single Market where non-tariff barriers are forcefully prohibited, and it also offers an 
opportunity to make comparisons among a more homogenous group of countries in terms of their political systems.

\section{Empirical model, data and econometric approach}

In our model of non-compliance with the free movement of goods in intra-EU trade we focus on both country-specific and industry-specific determinants, emphasizing among the first, various characteristics of the domestic institutional environment. The reduced form of our model is thus specified as:

$$
\mathrm{NTBs}_{i j t}=f\left(\mathbf{I}_{j t}, \mathbf{X}_{i j t}, \mathbf{Z}_{j t}\right)
$$

where, $\mathrm{NTB}_{i j t}$ denotes the prevalence of non-tariff barriers based on the number of infringements in industry $i$ of country $j$ at time period $t, \mathbf{I}_{j t}$ is a vector of institutional variables that vary across countries and time period, and $\mathbf{X}_{i j t}$ and $\mathbf{Z}_{j t}$ are vectors of industry- specific and country-specific control variables, respectively.

\subsection{Infringements at country-and industry-level}

NTBs constitute infringements to EU law as they violate articles 28 and 30 of the EC Treaty on the free movement of goods. Therefore, non-compliance can be taken as a measure of protection. Similarly to the UNCTAD database on non-tariff measures, our source of information is based on complaints and notifications (Bora et al. 2002), in the present case to the EU Commission. Anyone may place a complaint against a member state in relation to national measures or practices that violate Community law and under article 226 of the EC Treaty (258 TFEU) the Commission may open an infringement proceeding. By initiating bilateral contacts - issuing letters of formal 
notice followed by reasoned opinions - the Commission tries to bring the infringement to an end; if the member state resists it may refer the case to the European Court of Justice. Our data refers to those cases the Commission issued at least a reasoned opinion.

This inventory approach allows for estimates of the frequency of Single Market non-compliance, however, do not intend to quantify or infer their impact in terms of trade flows, nor do they provide information on the seriousness of the infringement in terms of its trade distortion effect. Indeed, as Mansfield and Busch (1995: 735) caution, "unlike tariffs, NTBs have no natural measure of intensity".

The data on infringements was collected from the Annual Reports on Monitoring the Application of Community Law and supplemented with the following EU publications: 'Décisions de la Commission sur l'Application du Droit Communautaire', 'Internal Market - Infractions to the Free Movement of Goods', and various issues of the 'Single Market News'. Therefore, our study includes exclusively situations of non-compliance with Treaty provisions, and does not comprise infringements upon sectoral harmonized rules (directives and regulations). As these non-compliance cases are not related to late or incorrect transposition of secondary EU law, it can be said that these infringements are non-accidental and result from a deliberate protectionist intention.

Our data has two major advantages. First, it covers all infringements to the free movement of goods opened by the EU Commission. Second, the infringements refer to both products and production processes. However, this data set has several limitations. First, the number of infringements may underestimate the actual NTBs 
existing in intra-EU trade, as they only capture violations that have been reported to the Commission. Second, the data set does not contain information on the specific type of non-tariff barrier used. Third, the infringements are not described with the same detail throughout the database, therefore in our own transcription of each infringement into the ISIC product classification we were constrained to using the 2digit classification. Our data comprises a panel of 14 EU countries $^{2}$ and 20 industries for the period 1994-2002. We observe 368 infringement proceedings.

The empirical distribution of the number of infringement shows interesting features of the data. Firstly, over the observed period, zero is the median and the modal, most frequent value, implying that a significant number of member countries' industries did not violate the free movement of goods at some point in the period. Overall, non-compliance ensuing from the use of NTBs appears not to be a highly frequent phenomenon, although there are some heavy infringing countries. Secondly, the variance significantly exceeds the mean, motivating a careful choice of the econometric approach. Finally, despite the number of infringements range from 0 to 15 , nearly $90 \%$ of country-industry pairs record zero infringements. These features support the use of count data models.

Another interesting feature of the data is the notable variation in the incidence of infringements across countries and industries. The three heaviest infringers (France,

2 Austria, Belgium, Denmark, Finland, France, Germany, Greece, Italy, Ireland, Netherlands, Spain, Portugal, Sweden and United Kingdom. Luxembourg was excluded due to lack of data. 
Italy and Germany) are EU large economies suggesting that large and politically strong member states are more able to avoid compliance and adopt a protectionist behavior, even against pressure from EU enforcement authorities, as they may benefit more from non-compliance with Single Market free movement of goods than small economies. In fact, the slightest infringers (Denmark, Ireland and Portugal), are three of the four EU countries in our study with lowest GDP. This data seems to provide support for the argument that small economies may not have the market power to benefit from optimal trade protection (Mansfield and Busch 1995).

The results also show that non-compliance varies considerably across industries and appears to be concentrated in a reduced number of industries. The three heaviest infringing industries account for 71.8 per cent of the infringements over the period. They are the food, beverages and tobacco industries, which are strongly engaged in lobbying national governments for protection (see, e.g. Goldberg and Maggi 1999), and where consumer safety concerns are often used as justification for illegitimate market protection. The food industry, particularly, is traditionally quite protected in the EU, not only in trade with third countries, but also in intra-EU trade; it is also subject to high levels of Community harmonization, which seems to indicate that member countries' infringements upon the free movement of goods are a form of circumventing existing EU harmonization. Conversely, intra-EU trade infringements are almost non-existent in wood and cork, leather and footwear industries. The great variability in the number of infringements across industries clearly indicates that non-compliance with free movement of goods in the Single Market is also industryspecific. 


\subsection{Measures of the institutional setting}

We consider four variables that cover the political, economic and legal aspects of the institutional setting. Specifically, the empirical variables are regulatory quality, rule of law, government effectiveness, and voice and accountability (Table 1). These variables are only available by country. Our main goal is to examine whether they explain why industries in some countries tend to resort more to NTBs that infringe upon the free movement of goods than in other countries.

According to the political economy models, protectionist trade policies are very much the result of political interests, which either emanate from certain interest groups or from politicians in the government. Voice and accountability (VACC) measures the degree of representativeness, i.e., how well the population and organized interests can make their voices heard and how mature and well established the political system of country $\mathrm{j}$ is. Thus, we can expect that the better these features of the institutional setting are, the less the power restricted groups in society will have. We expect a negative relationship between this variable and a country's propensity to use infringements related to the use of NTBs.

A country's government effectiveness also has an impact on economic activity. The better the expertise of bureaucrats and the better and quicker decisions are made, the lower the costs and more easily domestic and foreign investors can go about their business. Better government quality also means higher transparency in public administration and higher independence from political interference. Therefore, we can expect the ability of pressure groups to lobby for Single Market non-compliance to be reduced. As such, the variable government effectiveness 
(GEFF) is expected to have a negative relationship with non-compliance resulting from member states' trade protection measures.

The economic regulatory framework in which firms operate is one of the relevant institutional characteristics that determine firms and markets outcomes. For instance, a strong anti-trust policy would be expected to reduce market power by reducing the size and power of incumbents (see, e.g., Kumar et al., 1999). Labor market regulation may also have strong impacts on markets dynamics. Rigid labor regulation may impose a disproportionate burden on younger and smaller firms (Davis and Henrekson 1997) by increasing adjustment costs in the labor market. On the other hand, market regulation has also been seen as a means by which large incumbent firms maintain their rents. Carlton (2004) argued that high entry costs may be imposed specifically to protect incumbents connected with the political elite.

A good quality of the regulatory environment (RQUA) would imply regulations that foster competitiveness and market entry. Firms and industries that attain high levels of competitiveness would lessen the use of political pressure for trade protection. However, a good quality of the regulatory environment may also leave some domestic firms and industries in distress. In this case, they would increase political pressures for trade protection. Hence, the distributional consequences of the regulatory environment might determine the strength of political pressures for trade protection resulting in infringement cases to the free movement of goods. In this sense, the qualitative impact of the regulatory environment on trade protection cannot be anticipated, remaining an empirical question. 
Another institutional feature that conditions firms and markets dynamics is the strength of a country's legal system, its ability to enforce contracts and protect property rights, and the strength of a normative belief that a rule ought to be obeyed regardless of whether it suits instrumental self-interests. Kumar et al. (1999) found that countries with greater judicial efficiency have larger firms, especially in low capital intensive industries. As strong rule of law implies higher transparency of the judicial system as well as better law enforcement, we expect lobbying activity to be less successful. Moreover, the sense of moral obligation associated with strong rule of law would imply a higher inclination of member states to comply with EU norms (Gibson and Caldeira 1996). The variable rule of law (RLAW) measures the quality of law enforcement in country $\mathrm{j}$ and we expect it to have a negative impact on noncompliance resulting from protectionist measures.

These institutional indicators were collected from the World Bank Governance Indicators database, where the concept of governance is understood as the traditions and institutions by which authority in a country is exercised (Kaufman 2009: 2) and includes three main dimensions - the process by which governments are selected, monitored and replaced, the capacity of the government to effectively formulate and implement sound policies, and the respect of citizens and the state for the institutions that govern economic and social interactions. The indicators are constructed to have a mean of zero and a standard deviation of one in each period. A higher value is indicative of better governance or stronger institutions. These measures are averaged over the years 1996, 1998, 2000 and 2002. Table 1 shows a description and some statistics of the institutional indicators. 


\section{Insert Table 1 here}

First, one should note some variation across countries with respect to their institutional setting. Second, the institutional characteristics with the highest variation across countries are, in the following order, government effectiveness, rule of law and regulatory quality; voice and accountability has the lowest variation. This seems to indicate that institutional characteristics relating to law enforcement, bureaucracy, and regulatory practices have a more important role in explaining EU cross border trade protection than the degree of representativeness in the political system. Third, the institutional features in which the fourteen EU countries have on average better performance are government effectiveness and rule of law, whereas the quality of the regulatory context has the lowest mean value. This is an interesting finding because most of the regulatory changes intended to increase harmonization within EU countries have been driven by the Single Market Program.

The results denote that despite the 1992 Program member states' regulatory quality is still wanting, which may be related to some resistance by EU member states' to changes in Single Market law. This argument is in line with Commission evaluations and with the literature on compliance with EU secondary law that show that member states tend to delay the adoption of new regulations, and tend not to correctly and fully transpose directives (European Commission 2009; Börzel et al. 2012; Mbaye 2001; Treib 2008).

\subsection{Control variables}

The vector of industry-specific control variables includes a measure for import penetration (MPEN), which is expected to have a positive effect on non-compliance 
ensuing from trade protection measures, as we follow Karacaovali and Limão (2008) in assuming that all the industries are politically organized to demand some kind of trade protection.

The degree of intra-industry trade (INTRA) is another factor that would affect firms' incentives to lobby for trade protection. Arguments based on economic distributional consequences of trade suggest that firms in a market where intraindustry trade prevails would lobby less vigorously for protection than firms in a market characterized by inter-industry trade. As intra-industry trade entails less redistributive effect and lower adjustment cost than inter-industry trade (Thede 2007), firms in a market with high intra-industry trade would gain less from trade protection and hence would have little incentives to lobby.

However, Gilligan (1997) argues that lobbying becomes a private good for the firms in a market where intra-industry trade prevails, as they are a monopolist in their particular variety and have no incentive to free-ride. The product differentiation that characterizes intra-industry trade reduces the number of firms protected by a particular trade barrier and thus increases the incentives for firms to act politically in a market where intra-industry trade prevails. The net impact of those economic and political incentives for firms lobbying for trade protection is theoretically ambiguous and hence an empirical issue.

The relative size of the industry in the economy (VASH) is as a proxy for its political importance and power. In addition, previous evidence has shown that industries with high capital intensity and human capital have more protection than labor intensive industries and/or with less skilled workers (Trefler 1993; Goldberg 
and Maggi 1999). As such, the vector of industry-specific control variables comprises also the variable research and development intensity (RDINT), expecting industries with higher R\&D intensity to be more demanding of protection.

The vector of time-varying country-specific variables comprises variables measuring the relative economic size of the $14 \mathrm{EU}$ member countries (GDPSH) and their wealth level (GDP). Previous literature provides various arguments to why size and income affects countries trade policies (see, e.g. Mansfield and Busch 1995; Steinberg 2002).

The industry-level data comes from OECD Stan database. Our sample includes all manufacturing industries at the 2-digit level of the ISIC Rev. 3 classification, except 'manufacturing not elsewhere classified' (ISIC 36 and 37), which being residual has been excluded; other industries have been aggregated due to lack of data. $^{3}$ The country-level data, GDP and population were collected from OECD Statistics.

\subsection{Econometric approach}

The non-negativity and discrete nature of the dependent variable - number of infringements - and its high frequency of zeros compel us to apply count data models. In these models, the observed heterogeneity is incorporated into the model through the mean, such as

\footnotetext{
${ }^{3}$ Food Products, Beverages and Tobacco (ISIC 15-16); Textiles and Textile Products (ISIC 17-18); Pulp, Paper, Paper Products, Printing and Publishing (ISIC 21-22); Basic Metals and Fabricated Metal Products (ISIC 27-28); Electrical and Optical Equipment (ISIC 30-33); Transport Equipment (ISIC 34$35)$.
} 


$$
E\left(N T B s_{i j t} \mid \mathbf{I}_{j t}, \mathbf{X}_{i j t}, \mathbf{Z}_{j t}\right)=\lambda_{i j t}=\exp \left(\mathbf{I}_{j t} \alpha+\mathbf{X}_{i j t} \beta+\mathbf{Z}_{j t} \gamma\right)
$$

where $\mathbf{I}_{j t}$ is a vector of institutional variables, $\mathbf{X}_{i j t}$ and $\mathbf{Z}_{j t}$ are vectors of control variables, and $\alpha, \beta$ and $\gamma$ the conformable vectors of coefficients. For all control variables, the estimation procedure uses one-year lagged measures, which are predetermined for contemporary levels of infringements and attempt to mitigate potential endogeneity problems.

Before discussing the estimates, we need to choose a count data model that deal with the particular features of the data - overdispersion and excess zeros. Alternative count data models seem substantially reasonable but they are econometrically different and are not necessarily easy to compare. Either unobserved heterogeneity, or a process that has separate mechanisms for generating zero and nonzero counts can produce both overdispersion and excess zeros in the raw data (Cameron and Trivedi 1998).

In the context of non-compliance with EU free movement of goods, zero infringements may occur in a given year, industry or country but a positive count could have been registered. On the other hand, some industries do not register any infringements and that will never occur given their industry-specific characteristics. They represent the group of "certain zeros". Therefore, industries/countries will look identical in the response variable but they have arrived at the same outcome through two different processes.

To account for those two different generating process, the zero-inflated (ZI) count models generate two separate models and then combine them. First, a logit model is generated for predicting whether or not an industry/country would be in the group 
of "certain zeros". In our model, industry-specific characteristics seem to be the chief determinants of the prevalence of zero outcomes and the different probabilities of transition from zero to positive number of infringements. Then, a count data model is generated to predict the counts for industries/countries that are not "certain zeros" based on equation (2). Table 2 shows tests and model fit statistics appropriate to comparison between alternative econometric models.

\section{Insert Table 2 here}

The Vuong (1989) test strongly prefers the ZI count data models over the Poisson and the negative binomial model, respectively, suggesting that there is a separate generating process for the zero and nonzero. Either the ZI Poisson or the negative binomial model could account for both the overdispersion and the excess zeros in the data, although these model fit statistics indicate that the negative binomial model is preferred over the ZI Poisson model. Together, these pieces of information lead to the choice of the ZI negative binomial model (ZINB).

Table 3 shows estimates for the selected models along with clustered standard errors, which allow for cluster-robust inference. To handle country-specific effects, the clustering was based on country-year groups. By clustering along these two dimensions, observations may be correlated within each country and each time period, but must be independent across countries and time.

Insert Table 3 here 


\section{How relevant is the institutional setting?}

Our estimates strongly suggest that after controlling for industry-specific characteristics the national institutional setting has an important role in explaining non-compliance resulting from member states' intra- EU trade protection measures. Voice and accountability (VACC), government effectiveness (GEFF) and regulatory quality (RQUA) are statistically significant, indicating that the institutional setting has power to explain the prevalence of infringements in intra-EU trade at industrylevel. The negative estimate of government effectiveness (GEFF) suggests that a high degree of independence from political pressures and quality of policy formulation and implementation reduces the propensity of EU countries to use non-compliance as NTBs. A similar effect is found for the degree of representativeness and freedom (VACC), indicating that the better this characteristic of the institutional setting, the less responsive governments will be to domestic industries demands for protection.

Conversely, the positive relationship between regulatory quality (RQUA) and prevalence of infringements means that the higher the regulatory quality the higher the probability of EU countries resorting to trade protection. These estimates suggest that increases in competition in the domestic market are motivating protectionist measures towards external competition, namely by using national regulatory barriers. These results corroborate previous evidence that domestic pressures are an important determinant of protection (see Becker and Theuringer 2001) and seem to be consistent with the view that in more industrialized and sophisticated economies subtler forms of capture and 'legal corruption' exist, and undue influence is often 
legally exercised by powerful private interests which influence national regulations and policies (Kaufman 2009).

With respect to control variables, we find that the country's relative size (GDPSH) contributes to explain protectionist behavior among EU countries resulting in non-compliance with Single Market legislation on free movement. This evidence is consistent with Mansfield and Busch (1995) that show that larger countries display a more pronounced interest in protection than their smaller counterparts.

On the industry-level side, the higher the import penetration ratio (MPEN), the share of intra-industry trade (INTRA) and R\&D intensity (RDINT), the lower is the probability of compliance with free movement of goods in intra-EU trade. Interestingly, MPEN and INTRA appear to be relevant to persuade a member state not to comply with free movement of goods, but they fail to explain the prevalence of a positive number of infringements. This result should, nonetheless, be read with caution as the lack of data on lobbying activity in the EU has compelled us to consider that all industries in the economy as organized, assuming that one way or another all industries exert some sort of pressure on policy makers. With respect to R\&D intensity, the estimates provide clear evidence that $R \& D$ intensive industries also have a higher demand for protection (cf. Ray 1981; Goldberg and Maggi 1999) and suggest that governments tend to protect those industries, whose firms profits they weigh quite heavily.

For robustness, we check if our results are sensitive to different types of industries by constructing two sub-samples, one for top infringing industries and the other for the lowest infringing industries. In both cases, and using the same statistical 
procedure to choose the appropriate count data model, the statistical information leads to the choice of the negative binomial model. The estimates are also reported in Table 3.

Overall, dividing the sample provided qualitatively similar results on the influence of the national institutional setting on compliance with Single Market legislation. This reinforces the empirical support for our main contention that the institutional setting explains member states' compliance with Single market law. The estimates show that government effectiveness (GEFF) and regulatory quality (RQUA) are relevant to explain non-compliance in both types of industries.

Interestingly, the top infringing industries report a positive and statistically significant relationship between the import penetration ratio and the number of infringements, suggesting that the traditional political economy hypothesis could be adequate to describe protection for some industries in intra-EU trade. On the other hand, non-compliance associated with the less infringing industries seems to be significantly influenced by the degree of intra-industry trade. In these industries, holding everything else constant, the degree of intra-industry trade seems to strongly increase the incentives for firms to act politically, lobbying for trade protection based on non-compliance with the free movement of goods. The R\&D intensity variable retains its statistical significance and positive association with non-compliance across sub-samples, whereas the industry value-added appears with a negative association with non-compliance suggesting that industries with some competitive leverage are less likely to engage in non-compliance. 


\section{Conclusions}

This paper aims at assessing whether EU member states institutional setting is a driving force for trade protection in intra-EU trade measured by non-compliance with the free movement of goods within the Single Market. We analyzed noncompliance cases with the free movement of goods among 14 EU member states over the period 1994-2002. Despite some limitations the data offered a unique opportunity to study trade protection across countries and industries of the EU common market that ostensibly prohibits protectionist practices, and does it and over time. As our dependent variable is a count variable and does not measure intensity or impact of protection, this study does not intend to assess whether non-compliance in one country is more (or less) harmful for the free movement of goods than in another country. Yet, several of our conclusions confirm the importance of the national institutional setting of EU member states to explain Single Market cross border trade protection.

The estimates strongly suggest that higher government independence from political pressures reduces the propensity of EU countries to use NTBs that infringe upon the free movement of goods. Similarly, the better the government representativeness and accountability the less responsive it will be to domestic demands for protection. As such, government effectiveness and accountability facilitate compliance with the free of movement of goods among EU member states.

Conversely, the higher the country regulatory quality the higher the probability the EU member state will resort to trade protection, suggesting that increases in competition in the domestic market motivate protectionist measures against other 
EU member states. Domestic firms' lobbying spawns national regulatory barriers that impair the free movement of goods. This result suggests that the ability of national governments to formulate and implement policies and regulations that promote competition among firms appears not to cross national borders.

These results provide EU policymakers with an argument to improve the quality of policy formulation and implementation in EU countries and to deepen integration of the Single Market. The ability to shape policy decisions that advance trade protection seems to be mainly driven by economic interests of national firms, which are well-matched with political pressures against foreign competition. To EU policymakers this suggests the need to better synchronize the deepening of the Single Market with member states' interests by forcefully addressing and monitoring noncompliance.

\section{References}

Angelova, M., Dannwolf, T. and König, T. (2012) How robust are compliance findings? A research synthesis, Journal of European Public Policy 19(8): 1269-91.

Aussilloux, V., Emlinger, C. and Fontagné, L. (2011) “What Benefits From Completing The Single Market?" La Lettre du CEPII No. 316. Paris: Centre d'Études Prospectives et d'Informations Internationales.

Becker, B. and Theuringer, M. (2001) Macroeconomic determinants of contingent protection: the case of the European Union. Zeitschrift fur Wirtschaftspolitik, 50(3): 35070. 
Belloc, M. and Guerrieri, P. (2008) Special interest groups and trade policy in the EU. Open Economies Review 19(4), 457-478.

Bora B., Kuwahara, A. and Laird, S. (2002) Quantification of Non-Tariff Measures. Policy issues in international trade and commodities Study Series, No.18, New YorkGeneva: United Nations, UNCTAD.

Börzel, T. (2000) “Why there is no 'southern problem'. On environmental leaders and laggards in the European Union", Journal of European Public Policy 7(1): 141-62.

Börzel, T., Hofmann, T. and Panke, D. (2012) Caving in or sitting it out? Longitudinal patterns of non-compliance in the European Union, Journal of European Public Policy 9(1): 454-71.

Börzel, T., Hofmann, T., Panke, D. and Sprungk, C. (2010) “Obstinate and Inefficient: Why Member States do not comply with European law, Comparative Political Studies 43(11): 1363-90.

Börzel, T. and Risse, T. (2003) Conceptualising the domestic impact of Europe. In K. Featherstone and C. Radaelli (eds), The Politics of Europeanization, Oxford: Oxford University Press: 57-80.

Busch, M.L. and Mansfield, E.D. (2011) Trade: Determinants of Policies. In Robert A. Denemark et al. (eds), The International Studies Compendium Project. Oxford: WileyBlackwell. 
Cameron, A.C., and Trivedi, P.K. (1998) Regression Analysis of Count Data. Cambridge: Cambridge University Press.

Carlton, D.W. (2004) Using economics to improve antitrust policy, Columbia Business Law Review 2: 283-333.

Chen, N. and Novy, D. (2011) “Gravity, Trade Integration, and Heterogeneity across Industries." Journal of International Economics 85(2): 206-21.

Chen, N. (2004) Intra-national versus International Trade in the European Union: Why Do National Borders Matter? Journal of International Economics 63(1), 93-118.

Davis, S.J., and Henrekson, M. (1997) Explaining national differences in the size and industry distribution of employment, NBER Working Paper 6246.

Djankov, S., La Porta, R., Lopez-de-Silanes, F. and Schleifer, A. (2002) The Regulation of Entry, Quarterly Journal of Economics 67(1): 1-37.

Duina, F. and Blithe, F. (1999) 'Nation-states and common markets: the institutional conditions for acceptance', Review of International Political Economy 6(4): 494-530.

Egan, M. and Guimarães, M.H. (2012) Compliance in the Single Market, Business and Politics, 14(4): 1-28.

Ehrlich, S.D. (2007) Access to Protection: Domestic Institutions and Trade Policy in Democracies, International Organization 61: 571-605. 
European Commission (2009) Internal Market Scoreboard. Luxembourg: Office for Official Publications of the European Communities, July, 19.

Gawande, K. and Bandyopadhyay, U. (2000) “Is Protection for Sale? Evidence on the Grossman-Helpman Theory of Endogenous Protection", Review of Economics and Statistics 82: 139-52.

Gibson, J.L., and Caldeira, G.A. (1996) The Legal Cultures of Europe, Law and Society Review 30: 55-85.

Gilligan, M. (1997) Lobbying as a Private Good with Intra-Industry Trade". International Studies Quarterly 41(3): 455-74.

Giuliani, M. (2003) Europeanization in Comparative Perspective: Institutional Fit and National Adaptation, in K. Featherstone and C. Radaelli (eds) The Politics of Europeanisation. Oxford: Oxford University Press: 134-57.

Goldberg, P.K. and Maggi, G. (1999) Protection for Sale: An Empirical Investigation, American Economic Review 89(5): 1135-55.

Grossman, G. and Helpman, E. (1994) "Protection for Sale", American Economic Review 84(4): 833-50.

Guimarães, M.H. (2010) “How pervasive are national regulations in intra-EU trade?”, The International Trade Journal 24(2): 35-51. 
Hartlapp, M. and Leiber, S. (2010) “The implementation of EU social policy: the 'southern problem' revisited", Journal of European Public Policy 17(4): 468-86.

Héritier, A., Kerwer, D., Knill, C., Lehmkuhl, D., Teutsch, M., and Douillet, A. (2001) Differential Europe: New Opportunities and Restrictions for Policymaking in the Member States. Lanham, MD: Rowman \& Littlefield.

Hille, P. and Knill, C. (2006) “It"s the Bureaucracy, Stupid. The Implementation of the Acquis Communautaire in EU Candidate Countries, 1999-2003", European Union Politics 7: 531-52.

Imai, S., Katayama, H., and Krishna, K. (2009) “Is protection really for sale? A survey and directions for future research", International Review of Economics and Finance 18(2): 181-91.

Karacaovali, B., and Limão, N. (2008) The Clash of Liberalizations: Preferential vs. Multilateral Trade Liberalization in the European Union. Journal of International Economics 74(2): 299-327.

Kaufman, D. (2009) On Governance, Rule of Law and Development: Some Concepts, Comparative Measures, and Reflections, Keynote Presentation at the Second Global Conference in Law \& Order Upgrade, Seoul, Korea, June $24^{\text {th }}$.

Kono, D.Y. (2009) "Market Structure, Electoral Institutions, and Trade Policy". International Studies Quarterly 53: 885-906. 
Kono, D.Y. (2006) “Optimal Obfuscation, Democracy and Trade Policy Transparency". American Political Science Review 100: 369-384.

Koutalakis, C., (2004) 'Environmental compliance in Italy and Greece: the role of nonstate actors', Environmental Politics 13(4): 754-74.

Kox, H., Dekker, P. Horst, A., Lejour, A., Straathof, B., Tammes, P. and Wennekers, C. (2007) "Market Place Europe - 50 years of market integration in the European Union." European Outlook 5, The Hague: Netherlands Institute for Social Research and Netherlands Bureau for Economic Policy Analysis.

Kumar, K, Rajan, R. and Zingales, L. (1999) What determines firm size?, NBER Working Paper 7208.

Laeven, L. and Woodruff, C. (2007) “The quality of the legal system, firm ownership and firm size", The Review of Economics and Statistics 89: 601-614.

Lee, J. and Swagel, P. (1997) Trade Barriers and Trade Flows Across Countries and Industries. The Review of Economics and Statistics 79(3): 372-82.

Linos, K., (2007) ‘How can international organizations shape national welfare states? Evidence from compliance with European Union directives', Comparative Political Studies 40(5): 547-70.

Mansfield, E. and Busch, M. (1995) “The Political Economy of Nontariff Barriers: A Cross-National Analysis", International Organization 49(4): 723-49. 
Mbaye, H.A.D. (2001) Why national states comply with supranational law: explaining implementation infringements in the European Union, 1972-1993. European Union Politics 2(3): 259-281.

Milner, H. (1999) The Political Economy of International Trade, Annual Review of Political Science 2: 91-114

Pelkmans, J. (2011) “The Case for 'more Single Market'." Policy Brief 234. Brussels: Center for European Policy Studies.

Ray, E. (1981) The Determinants of Tariff and Nontariff Restrictions in the US. The Journal of Political Economy 89(1): 105-21.

Rogowski, R. (1987) Trade and the Variety of Democratic Institutions. International Organization, 41(2): 203-23.

Steinberg, R. H. (2002) In the Shadow of Law or Power? Consensus-Based Bargaining and Outcomes in the GATT/WTO. International Organization 56(02): 339-74.

Thede, S. (2007) Determinants of Bilateral Trade Protection. The World Economy 28(3): 313-28.

Trefler, D. (1993) Trade Liberalization and the Theory of Endogenous Protection: An Econometric Study of U.S. Import Policy. Journal of Political Economy 101(1): 138-60. 
Treib, O. (2008) "Implementing and Complying with EU Governance", Living Reviews in European Governance 3(5). http://www.livingreviews.org/lreg-2008-5. Accessed 8 June 2012.

Vuong, Q.H. (1989) Likelihood ratio tests for model selection and non-nested hypotheses. Econometrica, 57: 307-333. 


\section{Table 1. Description of Explanatory variables and descriptive statistics}

Variable Description Mean Std.

Institutional variables

RQUA

Regulatory quality: ability of the government to effectively 1.234

$0.343 \quad 0.284$

1.925 formulate and implement sound policies and regulations that facilitate doing business and promote competition and private sector development.

RLAW

Rule of law: extent to which agents have confidence in and
abide by the rules of society; in particular, quality of contract

$\begin{array}{lll}1.546 & 0.454 & 0.162\end{array}$ enforcement, police and courts, and likelihood of crime and violence.

GEFF

Government effectiveness: quality of public services, of civil

1.680

$0.496 \quad 0.164$ service and degree of its independence from political
pressures, quality of policy formulation and implementation, and credibility of the government commitment to such policies.

VACC

Voice and Accountability: extent to which citizens are able to 1.290 participate in selecting their government, freedom of expression and association, and free media.

\section{Control variables}

Industry-level variables

MPEN

Import penetration ratio, i.e., imports/(imports + output - 0.570 exports).

INTRA

The Grubel-Lloyd index for industry $I$, calculated as 1- 0.761 (|EXPO-IMPO|/EXPO+IMPO)); varies between zero (pure inter-industry trade) and one (pure intra-industry trade).

VASH Value added share of industry $i$ relative to the total economy.

0.079

$0.332-0.000$

RDINT

R\&D intensity, calculated as the ratio of R\&D expenditures by $\begin{array}{llll}1.142 & 2.037 & 0\end{array}$ industry to its production.

Country-level variables

GDP

Logarithm of GDP, per capita, USD, millions, constant prices, 2.971

$0.303 \quad 1.893$ 
Table 2. Tests and fit statistics for alternative count data models

\begin{tabular}{lcclc}
\hline Models & $\Delta$ BIC & $\Delta$ AIC & $\begin{array}{l}\text { Vuong statistic } \\
(\mathrm{p} \text {-value })\end{array}$ & Decision \\
\hline Poisson vs. NegBin & 82.6 & 0.07 & - & NegBin preferred over Poisson \\
Poisson vs. ZI-Poisson & 59.3 & 0.07 & 4.14 & ZI-Poisson preferred over Poisson \\
& & & $(0.000)$ & Negbin preferred over ZI-Poisson \\
NegBin vs. ZI-Poisson & -23.3 & 0.002 & - & ZINB preferred over NegBin \\
NegBin vs. ZINB & -11.5 & 0.01 & 2.66 & \\
& & & $(0.004)$ & ZINB preferred over ZI-Poisson \\
ZINB vs. ZI-Poisson & -11.8 & -0.01 & - &
\end{tabular}




\begin{tabular}{|c|c|c|c|c|c|c|c|c|}
\hline \multirow[b]{3}{*}{ Variable } & \multirow{2}{*}{\multicolumn{2}{|c|}{ NegBin }} & & & \multicolumn{2}{|c|}{$\begin{array}{l}\text { Top infringer } \\
\text { industries } \\
\end{array}$} & \multicolumn{2}{|c|}{$\begin{array}{c}\text { Bottom infringer } \\
\text { industries }\end{array}$} \\
\hline & & & \multicolumn{2}{|c|}{ ZINB } & \multicolumn{2}{|c|}{ NegBin } & \multicolumn{2}{|c|}{ NegBin } \\
\hline & Estimates & s.e. & Estimates & s.e. & Estimates & s.e. & Estimates & s.e. \\
\hline \multicolumn{9}{|l|}{ Count equation } \\
\hline \multicolumn{9}{|c|}{ Institutional variables } \\
\hline VACC & $-2.106^{* *}$ & 0.996 & $-2.103^{* *}$ & 0.995 & -1.321 & 0.894 & -4.016 & 4.497 \\
\hline GEFF & $-0.951^{\star * *}$ & 0.240 & $-0.979 * * *$ & 0.260 & $-0.953^{* * *}$ & 0.232 & $-1.177^{*}$ & 0.667 \\
\hline RQUA & $1.427^{* * *}$ & 0.452 & $1.335^{\star * *}$ & 0.454 & $0.954^{* *}$ & 0.422 & $2.811^{*}$ & 1.691 \\
\hline RLAW & -0.275 & 0.368 & -0.231 & 0.378 & 0.129 & 0.357 & -2.329 & 1.733 \\
\hline \multicolumn{9}{|l|}{ Control variables } \\
\hline MPEN & 0.007 & 0.021 & -0.035 & 0.033 & $0.391^{* *}$ & 0.190 & 0.002 & 0.021 \\
\hline INTRA & $1.188^{* * *}$ & 0.426 & 0.273 & 0.510 & 0.134 & 0.523 & $2.608^{* * *}$ & 1.010 \\
\hline RDINT & $0.286^{* * *}$ & 0.034 & $0.195^{\star * *}$ & 0.042 & $0.076^{\star * *}$ & 0.026 & $1.044^{* *}$ & 0.535 \\
\hline VASH & -0.218 & 0.259 & $-0.508^{*}$ & 0.278 & $-0.833^{*}$ & 0.440 & $-3.269^{* *}$ & 1.361 \\
\hline GDP & -0.015 & 0.021 & -0.024 & 0.021 & 0.005 & 0.020 & -0.057 & 0.125 \\
\hline GDPSH & $2.600^{*}$ & 1.371 & $3.205^{* *}$ & 1.352 & $5.360^{* * *}$ & 1.511 & -0.061 & 7.904 \\
\hline Intercept & 0.010 & 0.690 & 1.633 & 0.670 & 0.173 & 0.664 & 1.022 & 1.923 \\
\hline \multicolumn{9}{|l|}{ Inflate equation } \\
\hline MPEN & - & - & $-2.315^{*}$ & 1.279 & - & - & - & - \\
\hline INTRA & - & - & $-2.100^{*}$ & 1.101 & - & - & - & - \\
\hline RDINT & - & - & $-0.693^{* * *}$ & 0.141 & - & - & - & - \\
\hline VASH & - & - & -0.941 & 1.068 & - & - & - & - \\
\hline Intercept & - & - & $2.732^{* * *}$ & 0.914 & - & - & - & - \\
\hline $\begin{array}{l}\text { Dispersion } \\
\text { parameter }(\alpha)\end{array}$ & $2.091^{* \star *}$ & 0.415 & $0.946^{* *}$ & 0.362 & $0.712^{\star \star \star}$ & 0.222 & 3.747 & 2.426 \\
\hline No. obs. & 1266 & & 1266 & & 490 & & 580 & \\
\hline $\begin{array}{l}\text { Log-likelihood } \\
\text { Wald test for }\end{array}$ & -651.5 & & -639.3 & & -451.3 & & -52.9 & \\
\hline $\begin{array}{l}\text { goodness-of-fit } \\
\text { McFadden }\end{array}$ & $134.2^{* * *}$ & & $84.57^{* \star *}$ & & $61.91^{* * *}$ & & $40.37^{* * *}$ & \\
\hline Pseudo-R ${ }^{2}$ & 0.086 & & 0.102 & & 0.065 & & 0.199 & \\
\hline
\end{tabular}




\section{Most Recent Working Paper}

NIPE WP Natália Barbosa, Maria Helena Guimarães e Ana Paula Faria, "Single Market non-compliance:

06/2013 how relevant is the institutional setting?", 2013

NIPE WP Lommerud, Kjell Erik, Odd Rune Straume e Steinar Vagstad, "Mommy tracks and public

05/2013 policy: On self-fulfilling prophecies and gender gaps in promotion”, 2013

NIPE WP $\quad$ Brekke, Kurt R., Luigi Siciliani e Odd Rune Straume, "Hospital Mergers: A Spatial

04/2013 Competition Approach", 2013

NIPE WP Faria, Ana Paula e Natália Barbosa, “Does venture capital really foster innovation?”, 2013

$03 / 2013$

NIPE WP

$02 / 2013$

NIPE WP Aguiar-Conraria, Luís, Teresa Maria Rodrigues e Maria Joana Soares, "Oil Shocks and the

01/2013 Euro as an Optimum Currency Area", 2013

NIPE WP Ricardo M. Sousa, "The Effects of Monetary Policy in a Small Open Economy: The Case of

27/2012 Portugal" 2012

NIPE WP Sushanta K. Mallick e Ricardo M. Sousa, "Is Technology Factor-Neutral? Evidence from the US

26/2012 Manufacturing Sector" 2012

NIPE WP Jawadi, F. e Ricardo M. Sousa, "Structural Breaks and Nonlinearity in US and UK Public Debt"

$25 / 2012 \quad 2012$

NIPE WP Jawadi, F. e Ricardo M. Sousa, "Consumption and Wealth in the US, the UK and the Euro Area:

24/2012 A Nonlinear Investigation" 2012

NIPE WP Jawadi, F. e Ricardo M. Sousa, “ Modelling Money Demand: Further Evidence from an

23/2012 International Comparison" 2012

NIPE WP Jawadi, F. e Ricardo M. Sousa, “Money Demand in the euro area, the US and the UK:

22/2012 Assessing the Role of Nonlinearity" 2012

NIPE WP Agnello, L, Sushanta K. Mallick e Ricardo M. Sousa, "Financial Reforms and Income

21/2012 Inequality" 2012

NIPE WP Agnello, L, Gilles Dufrénot e Ricardo M. Sousa, “Adjusting the U.S. Fiscal Policy for Asset

20/2012 Prices: Evidence from a TVP-MS Framework t" 2012

NIPE WP Agnello, L e Ricardo M. Sousa, "Fiscal Adjustments and Income Inequality: A First

19/2012 Assessment" 2012

NIPE WP Agnello, L, Vitor Castro e Ricardo M. Sousa, "Are there change-points in the likelihood of a

$18 / 2012$ fiscal consolidation ending?" 2012

NIPE WP Agnello, L, Vitor Castro e Ricardo M. Sousa, "What determines the duration of a fiscal

$17 / 2012$ consolidation program?" 2012

NIPE WP Veiga, Linda, "Voting functions in the EU-15", 2012

$16 / 2012$

NIPE WP Alexandre, Fernando e Pedro Bação, "Portugal before and after the European Union: Facts on

$15 / 2012$ Nontradables", 2012

NIPE WP Esteves, Rosa Branca e Carlo Reggiani, "Behaviour-Based Price Discrimination with Elastic

14/2012 Demand", 2012

NIPE WP Afonso, Oscar, Sara Monteiro, Maria Thompson “ Innovation Economy, Productive Public

13/2012 Expenditures and Economic Growth ", 2012

NIPE WP Esteves, Rosa Branca “Price Discrimination with Private and Imperfect Information”, 2012

$12 / 2012$

NIPE WP Castro, Vítor "Macroeconomic determinants of the credit risk in the banking system: The case of

$11 / 2012$ the GIPSI", 2012

NIPE WP Bastos, Paulo, Natália Pimenta Monteiro e Odd Rune Straume "Privatization and corporate

10/2012 restructuring", 2012

NIPE WP Castro, Vítor e Rodrigo Martins "Is there duration dependence in Portuguese local

09/2012 governments' tenure?", 2012

NIPE WP Monteiro, Natália Pimenta e Geoff Stewart “ Scale, Scope and Survival: A Comparison of

08/2012 Labour-Managed, and Capitalist Modes of Production", 2012 